\title{
Microsporogenesis of Betula oycoviensis Bess. and of its progeny
}

\author{
ANNA SZWABOWICZ
}

Department of Plant Variability, Institute of Botany, Polish Academy of Sciences, Kraków

(Received: March 1, 1976)

\begin{abstract}
The crossing of two spécimens of Betula oycoviensis Bess. described as a separate taxon of the subsection Albae, unexpectedly yielded a progeny among which three types were distinguished: oycoviensis, verrucosa, and nova, in the approximate ratio $1: 2: 1$. The first itwo types were trees, whereas the third one was a small shrub. Moreover, the three types of birches differed from one another in a number of morphological and biological characters. Microsporogenesis was investigated in the parental specimens of B. oycoviensis and in several specimens of the progeny representing three types of birches. It was only one birch of the oycoviensis type, a mixoploid specimeu, that exhibited disturbances in microsporogenesis. In the other examined birches of the oycoviensis, verrucosa, and nova types meiosis proceeded normally and resulted in normally developed tetrads and pollen grains. Therefore, $B$. oycoviensis belongs to hybrids of regular meiosis, its hybrid character being revealed only at crossing.
\end{abstract}

\section{INTRODUCTION}

Betula oycoviensis from the Ojców region, described for the first time by $\mathrm{B}$ esser in 1809, had for many years been regarded as one of the taxons of the subsection Albae Regel (W in k le r 1904). A detailed diagnosis of this species was given in 1921 by J. J enty s-S zaferowa. who next characterized it with an increasing precision on the basis of specimens from natural localities ( $J$ en ty s-S z a f er ow a 1928, 1951, 1953) and undertook several experiments in the breeding of this birch (J e n t y s-S z a f e r ow a 1967; J e n t y s-S z a f er ow a, Bi ałobrzeska, Truchanowicz, Więckowska 1974). These investigations, carried out in the Department of Plant Variability of the Institute of Botany of the Polish Academy of Sciences in Kraków, were started in 1954 by sowing of the nutlets derived from open pollination and gathered from the specimens of $B$. oycoviensis growing wild in the villages of Karnio- 
wice and Hamernia. The thus obtained seedlings segregated into two groups: $B$. oycoviensis and $B$. verrucosa in an approximate ratio $1: 1$ (Korczyk 1967a; W i ęckowska 1967). When planted in the experimental plot in the Botanic Gardens in Kraków, they were given the name of generation A. However, as a result of controlled crossings in 1957 one specimen of B. oycoviensis from generation A (No. 39), pollinated with the pollen of B. oycoviensis brought to the Botanic Gardens from Hamernia in 1920, was found to have unexpectedly yielded the progeny belonging to three types: verrucosa, oycoviensis, and nova, and amounting to 23, 48 , and 13 specimens respectively, thus approximating to the ratio $1: 2: 1$. This phenomenon recurred when in the following year another specimen of $B$. oycoviensis from generation A (No. 8) became pollinated with the pollen of the same B. oycoviensis as had been used in the first case. Again three types of birches were obtained, this time 15 specimens of the verrucosa type, 30 of the oycoviensis type, and 10 of the nova type. The progeny of B. oycoviensis No. 39 was called generation B, and that of the specimen No. 8 - generation C. With a lapse of a few years the seedlings of the oycoviensis and verrucosa types grew into large trees, whereas those of the nova type developed into small shrubs. These three types of birches varied from one another not only in height but also in several morphological and biological characters (Plate I; J en ty s-S z a f e r ow a 1967; J enty s-S z a f er ow a et al. 1974).

The nova type, given this provisional name by J enty s-Szafer ow a (1967), was first obtained experimentally and then was found in a natural locality in the Kobylańska Valley (K o r c z y k 1967b). This locality was interesting insomuch as around a solitary old tree of $B$. oycoviensis there grew out a coppice of young birches: $B$. oycoviensis, B. verrucosa, and $B$. nova, which most probably had germinated from the seeds of the old birch due to self-pollination. One of the specimens of $B$. nova has survived till now on the edge of the ravine and is easy to find.

The interesting fact of segregation of the progeny of B. oycoviensis $X$ $B$. oycoviensis stimulated further various controlled pollinations and also made it necessary to perform a cytological analysis of the parental specimens as well as of their progeny representing three types of birches. This last task was undertaken by the present author. She carried out the investigations of pollen and karyology ( $\mathrm{S} z \mathrm{w}$ a b ow i c z 1971, 1972), and, in the present study, of microsporogenesis in Betula oycoviensis and in its progeny comprising the oycoviensis, verrucosa, and nova types.

\section{MATERIAL AND METHODS}

The investigated material consisted of the male catkins of birches growing in an experimental plot in the Botanic Gardens in Krakow and of those growing wild in the Kobylańska Valley (Tables 1 and 2). For 
Table 1

Investigated specimens of Betula oycoviensis Bess. and its progeny

\begin{tabular}{|c|c|c|c|}
\hline Origin & Generation* & Species or Type** & Specimen \\
\hline Hamernia & - & oycoviensis & $\begin{array}{l}\text { B. oycoviensis } \\
\text { Bot. Gardens }\end{array}$ \\
\hline $\begin{array}{l}\text { Hamernia } \\
\text { B. oycoviensis } \\
\text { open pollination }\end{array}$ & A & oycoviensis & No 39 \\
\hline $\begin{array}{l}\text { B. oycoviensis No } 39 / \mathrm{A} \\
\times \text { B. oycoviensjs } \\
\text { Bot. Gardens }\end{array}$ & B & $\begin{array}{l}\text { oycoviensis } \\
\text { oycoviensis } \\
\text { oycoviensis } \\
\text { verrucosa } \\
\text { verrucosa } \\
\text { nova } \\
\text { nova } \\
\text { nova } \\
\text { nova }\end{array}$ & $\begin{array}{rr}\text { No } & 19 \\
\text { No } & 62 \\
\text { No } & 81 \\
\text { No } & 5 \\
\text { No } & 43 \\
\text { No } & 30 \\
\text { No } & 46 \\
\text { No } & 65 \\
\text { No } & 84\end{array}$ \\
\hline $\begin{array}{l}\text { B. oycoviensis } \text { No } 8 / \mathrm{A} \\
\times \text { B. oycoviensis } \\
\text { Bot. Gardens }\end{array}$ & $\mathrm{C}$ & $\begin{array}{l}\text { oycoviensis } \\
\text { verrucosa } \\
\text { nova } \\
\text { nova }\end{array}$ & $\begin{array}{lr}\text { No } & 15 \\
\text { No } & 21 \\
\text { No } & 1 \\
\text { No } & 3\end{array}$ \\
\hline $\begin{array}{l}\text { B. oycoviensis No } 39 / \mathrm{A} \\
\text { self-pollination }\end{array}$ & $\mathrm{H}_{5}$ & $\begin{array}{l}\text { oycoviensis } \\
\text { oycoviensis }\end{array}$ & $\begin{array}{l}\text { No } 401 \\
\text { No } 463\end{array}$ \\
\hline $\begin{array}{l}\text { B. verrucosa } \text { No } 107 / \mathrm{A} \\
\times \text { B. nova mixture of } \\
\text { pollen/B }\end{array}$ & $\mathrm{H}_{6}$ & oycoviensis & No 16 \\
\hline $\begin{array}{l}\text { B. nova } \text { No } 30 / \text { B } \\
\times \text { B. verrucosa Wolski Wood }\end{array}$ & $\mathrm{H}_{7}$ & oycoviensis & No 141 \\
\hline $\begin{array}{l}\text { B. nova } \text { No } 65 / \mathrm{B} \\
\text { self-pollination }\end{array}$ & $\mathrm{H}_{9}$ & nova & No 588 \\
\hline $\begin{array}{l}\text { B. nova No } 84 / \mathrm{B} \\
\text { self-pollination }\end{array}$ & $\mathrm{H}_{12}$ & nova & No 800 \\
\hline $\begin{array}{l}\text { B. nova } \text { No } 84 / \mathrm{B} \\
\times \text { B. nova mixture of } \\
\text { pollen } / B\end{array}$ & $\mathrm{H}_{13}$ & nova & No 715 \\
\hline $\begin{array}{l}\text { B. nova } \text { No } 36 / \mathrm{B} \\
\times \text { B. nova } \text { No } 84 / \mathrm{B}\end{array}$ & $\mathrm{H}_{14}$ & $\begin{array}{l}\text { nova } \\
\text { nova } \\
\text { nova }\end{array}$ & $\begin{array}{l}\text { No } 627 \\
\text { No } 661 \\
\text { No } 671\end{array}$ \\
\hline $\begin{array}{l}\text { Kobylańska Valley } \\
\text { B. oycoviensis } \\
\text { B. oycoviensis } \\
\text { self-pollination }\end{array}$ & . & $\begin{array}{l}\text { oycoviensis } \\
\text { nova }\end{array}$ & $\begin{array}{l}\text { B. oycoviensis } \\
\text { young birch } \\
\text { Kobylańska Valley } \\
B . \text { nova } \\
\text { Kobylańska Valley }\end{array}$ \\
\hline
\end{tabular}

* Birch generations derived from controlled pollinations performed in particular years from 1954 onwards are denoted with successive letters of the alphabet. The term "generation $\mathbf{H}$ " covers the specimens obtained after several various pollinations executed in 1962.

** The term "species" refers to the specimens from natural localities, and "type" to those from controlled pollination. 
.Table 2

Microsporogenesis in Betula oycoviensis Bess. and its progeny

\begin{tabular}{|c|c|c|c|c|c|c|c|c|c|c|}
\hline \multirow{3}{*}{$\begin{array}{l}\text { Name } \\
\text { of specimen } \\
\text { and progeny }\end{array}$} & \multirow{3}{*}{ 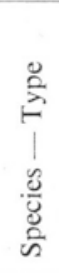 } & \multicolumn{8}{|c|}{ Observed stages } & \multirow[b]{3}{*}{$\mathrm{n}$} \\
\hline & & \multicolumn{3}{|c|}{ Division I } & \multicolumn{3}{|c|}{ Division II } & \multirow[b]{2}{*}{$\underset{\tilde{E}}{\tilde{E}}$} & \multirow[b]{2}{*}{ 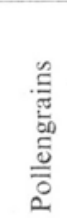 } & \\
\hline & & 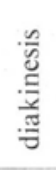 & 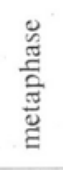 & 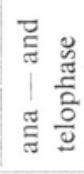 & 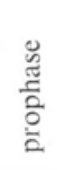 & 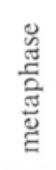 & 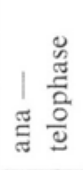 & & & \\
\hline $\begin{array}{l}\text { B. oycoviensis } \\
\text { Bot. Gardens } \\
\text { No. } 39 / \mathrm{A} \\
\text { No. } 19 / \mathrm{B} \\
\text { No. } 62 / \mathrm{B} \\
\text { No. } 81 / \mathrm{B} \\
\text { No. } 15 / \mathrm{C} \\
\text { No. } 401 / \mathrm{H}_{5} \\
\text { No. } 463 / \mathrm{H}_{5} \\
\text { No. } 16 / \mathrm{H}_{6} \\
\text { No. } 141 / \mathrm{H}_{7} \\
\text { B. oyc. young } \\
\text { Kobyl. Valley }\end{array}$ & 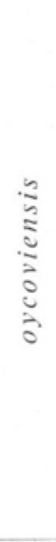 & + & + & $\begin{array}{l}+ \\
+\end{array}$ & + & $\begin{array}{l}+ \\
+ \\
+ \\
+\end{array}$ & $\begin{array}{l}+ \\
+ \\
+\end{array}$ & $\begin{array}{l}+ \\
+ \\
+ \\
+ \\
+ \\
+ \\
+ \\
+ \\
+\end{array}$ & $\begin{array}{l}+ \\
+\end{array}$ & $\begin{array}{c}14 \\
14 \\
\text { distur- } \\
\text { bances } \\
14 \\
14 \\
14 \\
14 \\
\\
14\end{array}$ \\
\hline $\begin{array}{lr}\text { No. } & 5 / \mathrm{B} \\
\text { No. } & 43 / \mathrm{B} \\
\text { No. } & 21 / \mathrm{C} \\
\end{array}$ & 气ू̆ & & & + & + & + & & $\begin{array}{l}+ \\
+\end{array}$ & + & 14 \\
\hline $\begin{array}{l}\text { No. } 30 / \mathrm{B} \\
\text { No. } 46 / \mathrm{B} \\
\text { No. } 65 / \mathrm{B} \\
\text { No. } 84 / \mathrm{B} \\
\text { No. } 1 / \mathrm{C} \\
\text { No. } 3 / \mathrm{C} \\
\text { No. } 588 / \mathrm{H}_{9} \\
\text { No. } 800 / \mathrm{H}_{12} \\
\text { No. } 715 / \mathrm{H}_{13} \\
\text { No. } 627 / \mathrm{H}_{14} \\
\text { No. } 661 / \mathrm{H}_{14} \\
\text { No. } 671 / \mathrm{H}_{14} \\
\text { B. nova } \\
\text { Kobyl. Valley }\end{array}$ & $\begin{array}{l}\simeq \\
\stackrel{\Xi}{\varrho} \\
\cong\end{array}$ & + & $\begin{array}{l}+ \\
+ \\
+\end{array}$ & + & + & + & + & $\begin{array}{l}+ \\
+ \\
+ \\
+ \\
+ \\
+ \\
+ \\
+ \\
+ \\
+ \\
+\end{array}$ & $\begin{array}{l}+ \\
+\end{array}$ & $\begin{array}{l}14 \\
14 \\
14\end{array}$ \\
\hline
\end{tabular}

the latter birches the names Betula oycoviensis, Betula verrucosa, and Betula nova were adopted, and the former were called the oycoviensis type, the verrucosa type, and the nova type respectively.

Out of a very ample material gathered between 1967 and 1974 only an insignificant part exhibited meiotic divisions. 
August 9th was the earliest and September 16th the latest date of fixation of the catkins in which various stages of division and tetrads were observed. However, microsporogenesis proceeded most frequently in the latter half of August.

The meiotic divisions did not occur simultaneously in the whole catkin. One and the same catkin, and even the same flower was found to contain anthers in various stages of development: from PMC's, through certain phases of divisions I and II, to the tetrads. Very often both sacs of one anther contained cells in different stages of meiosis.

The birches did not yield themselves readily to cytological analysis. Besides the difficulty of fix male catkins of appropriate age, another difficulty arose from a small size of the chromosomes, so that even tiny granulations in the cytoplasm obscured the picture.

The material to be studied was usually fixed in acetic alcohol $(3: 1)$ or in a mixture of anhydrous ethanol, chloroform and glacial acetic acid $(6: 3: 1)$, being sometimes pretreated with an 8 -hydroxy-quinoline solution. While preparing microscopic samples, the author first executed permanent squashes by Murin's (1960) cellophane method, the material being previously softened for 10 minutes in a mixture of $96 \%$ ethanol and concentrated hydrochloric acid. Better results were obtained by embedding fragments of catkins in paraffin and subsequently cutting them into $10 \mu \mathrm{m}$ thick sections. Both the squashes and microtome sections were stained with gentian violet or with Merck's methyl violet by Newton's technique.

Observations were carried out on a Reichert microscope with the use of immersion lens $100 \times$ combined with Zeiss eyepieces $20 \times, 25 \times$, and $32 \times$. Microphotographs were taken with the Reichert eyepiece Plan $12 \times$.

\section{RESULTS}

\section{Size of chromosomes}

The length of the mitotic chromosomes of B. oycoviensis, B. verrucosa, and $B$. nova, calculated during karyological examinations, approximated to $0.4-1 \mu \mathrm{m}$ (S z w a b o w i c z 1972).

During metaphase $I$ the bivalents of $B$. oycoviensis and $B$. nova were from c. 0.4 to $0.7 \mu \mathrm{m}$ long. $B$. verrucosa did not reveal the presence of metaphase I. The length of chromosomes during metaphase II ranged from c. 0.4 to $0.8 \mu \mathrm{m}$ for all three types of birches. Insignificant discrepancies between the lengths of chromosomes during mitosis in the somatic and reproductive cells might have been due to an error in calculations from the drawing. 


\section{Meiotic divisions}

\section{Betula oycoviensis (oycoviensis type)}

Various stages of microsporogenesis were observed in 10 specimens of $B$. oycoviensis derived from natural localities (B. oycoviensis) as well as from experimental breeding (oycoviensis type), two of them being found to contain tetrads only (Tables 1 and 2).

In the early stages of prophase I, following those of synizesis (Plate II a), the chromosomes of the studied birches were too poorly visible to lend themselves to observation (Plate II b).

Diakinesis was recorded in B. oycoviensis No. 16 from generation $\mathrm{H}_{6}$ obtained together with other specimens of this generation by experimental pollination of the verrucosa type with the pollen of the nova type. In the majority of the examined nuclei the conjugation of chromosomes proceeded in a normal way so that 14 bivalents were observable in them (Fig. 1 a). A few nuclei exhibited a less distinct picture on account of the staining of some parts of the nuclear membrane, which, added to the small size of chromosomes made the observation difficult. However, it may be presumed with a high degree of probability that these meiocytes did not depart from a norm.

The subsequent meiotic stages were noted in a number of specimens of B. oycoviensis (Table 2). The course of these stages was normal in all the examined specimens except for the birch No. 62 from generation B. In metaphase I there occurred 14 bivalents (Fig. 1 b), and in telophase I 14 chromosomes.

In the successive stage, two interkinetic nuclei were produced in the meiocytes but no cell wall was formed in these cells, although now and a temporary, very poorly visible cell plate could be discerned (Plate III a).

The interkinetic nuclei entered upon a fairly marked prophase of division II, in which the chromosomes could be counted.

Metaphase II as well as ana- and telophase II were quite normal. Both the two plates of metaphase II and four groups of ana-telophase II contained 14 chromosomes each (Fig. 2a, b; Plates III b and IV a).

The great majority of the tetrads of the examined specimens were normally developed (Plate IV b). The microcytes were encountered only sporadically. In B. oycoviensis No. 19 from generation B, for instance, one in 200 examined tetrads contained two smaller cells besides four cells of normal appearance. Likewise, in the case of a young B. oycoviensis from the Kobylanska Valley, among 500 tetrads the author discovered two microcytes and a tetrad with cells of different size: one cell was much smaller than the remaining three. The occurrence of a whole anther of the specimen No. 19 from generation B which contained tetrads with deformed cells should be regarded as one of major deviations from a norm. 
It is difficult to establish what has brought about this kind of anomaly, nevertheless it does not seem likely to have been induced by a disturbance in the course of meiosis, since then the cells of the tetrads would differ
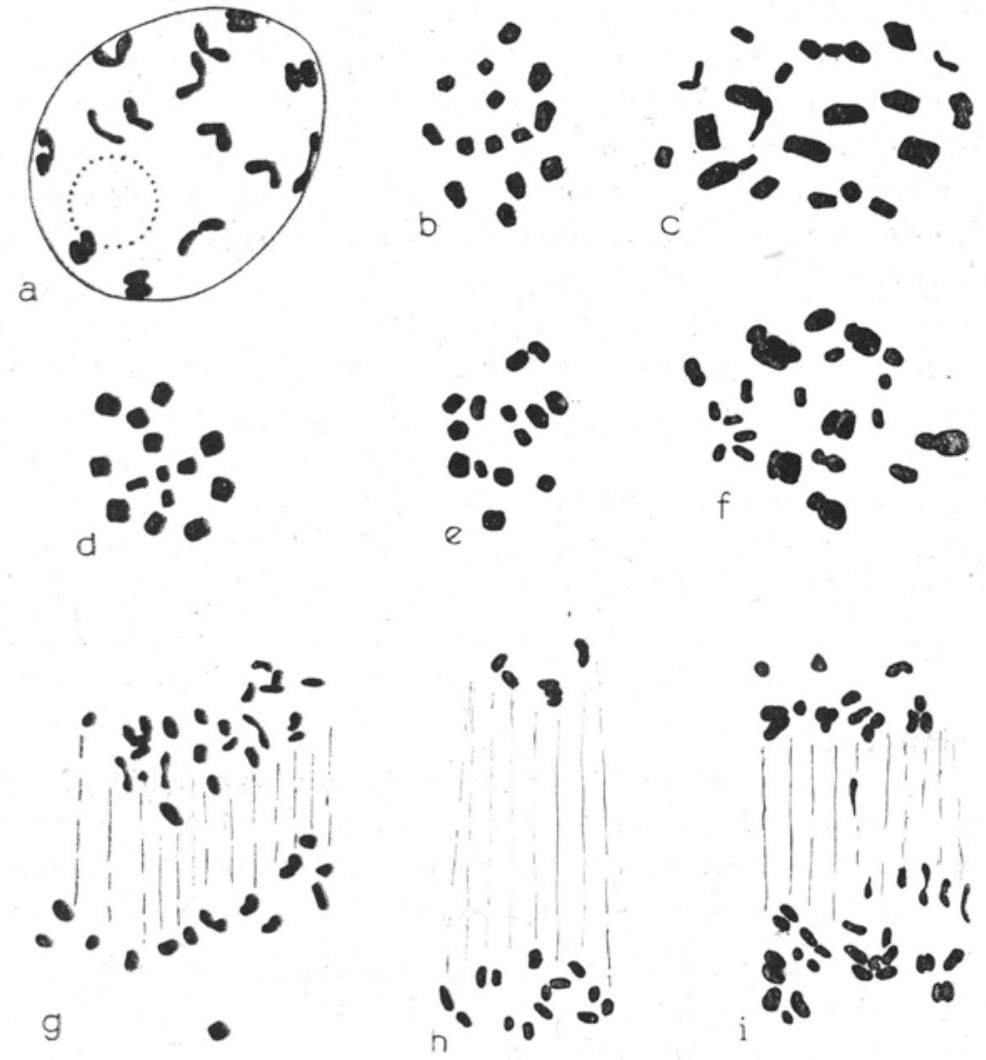

$10 \mu \mathrm{m}$

Fig. 1. Meiotic division I. a - diakinesis in specimen No, $16 / \mathrm{H}_{6}$ of oycoviensis type; b - metaphase $I$ in specimen No. $16 / \mathrm{C}$ of oycoviensis type; c, $\mathrm{f}$ - metaphase I disturbed in birch No. $62 / \mathrm{B}$ of oycoviensis type; $\mathrm{g}, \mathrm{h}, \mathrm{i}-$ anaphase $\mathrm{I}$ in birch No. 62/B; d - metaphase I in birch No. 84/B of nova type; e - metaphase I in B. nova from the Kobylańska Valley

from one another in size, besides, numerous microcytes would occur. Perhaps in such cases the deformation of the cells was evoked by external stimuli.

The only specimen exhibiting a marked deviation from a norm was the mixoploid birch No. 62 from generation B.

A lot of meiocytes of this birch showed a higher or lower degree of deformation. Some of pollen-sacs were filled with degenerated cells, whe- 
reas others contained cells deformed in various ways, e.g. flattened or invaginated. Even the cells undergoing meiotic divisions were often deformed.
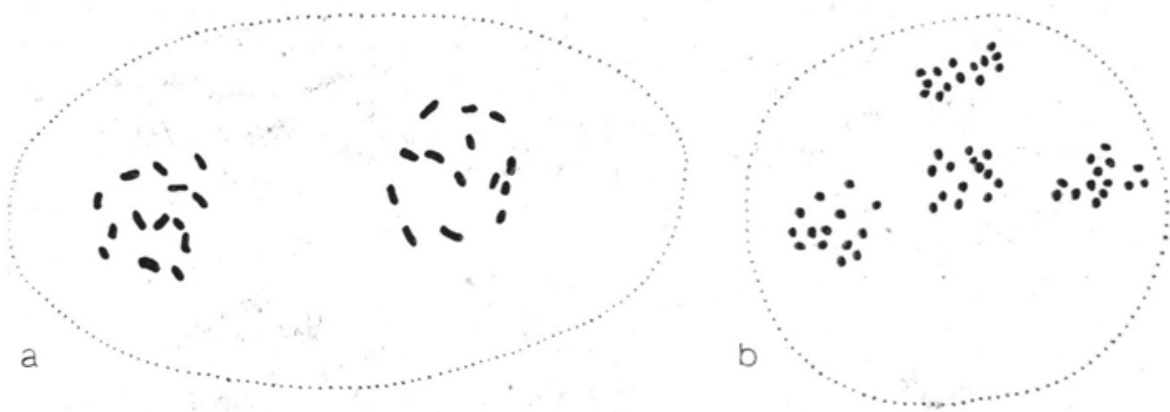

$10 \mu \mathrm{m}$

Fig. 2. Meiotic division II. a - metaphase II in B. oycoviensis from the Botanic Gardens; b - telephase II in B. oycoviensis No. 39/A.

In metaphase I, this birch was found to contain generally 21 to 24 configurations instead of 14 bivalents, and individual cells 13, 16, 17, 20 as well as 26 and 28 configurations, this being sometimes accompanied by the occurrence of tiny chromosome fragments. The term "configuration" was used because of the impossibility to determine whether these were uni-, bi-, or polyvalents (Table 3 a; Fig. 1 c and f; Plate III c).

Likewise, the course of anaphase and telophase I was highly abnormal. Among the major anomalies in these two stages were, above all, the migration towards the poles not only of individual chromosomes but from time to time also of indivisible bivalents or eventual polyvalents, a frequent occurrence of lagging chromosomes in the spindle, an occasional appearance in the cytoplasm of chromosomes or chromosome groups expelled from the spindle, and, finally, an uneven distribution of chromosomes at the two poles (Table 3 b; Fig. 1 g, h, i; Plate III d, e).

In metaphase II, the fact that the plates of the meiocyte were placed perpendicularly to each other prevented the counting of the chromosomes in both plates. Moreover, in several plates the chromosomes were connected on account of stickiness, which made impossible the establishment of their exact number. None the less, it was possible to discern that the two plates of numerous meiocytes differed from each other in the number of chromosomes and that in several plates the number of chromosomes exceeded 14. In metaphase II, much more frequently than in anaphase I, one or even two groups of chromosomes were found to have been expelled from the spindle (Table $3 \mathrm{c}$; Fig. $3 \mathrm{a}, \mathrm{b}$ ). 
$\mathrm{Pl}$ a te I

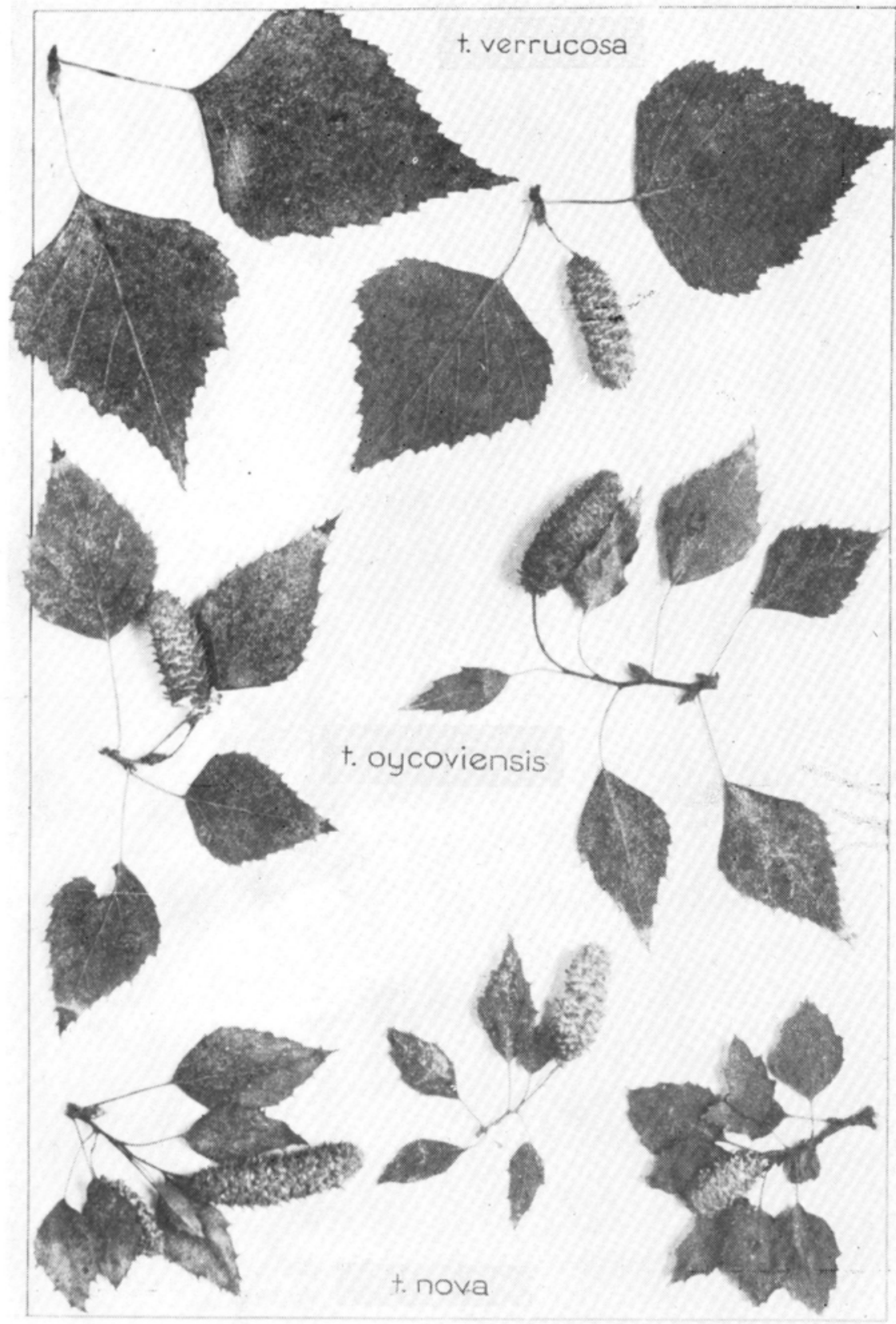

Leaves of three types of birches - progeny of Betula oycoviensis (after J. J e n t y s - S z a f e r o w a 1967,1974$)$. 

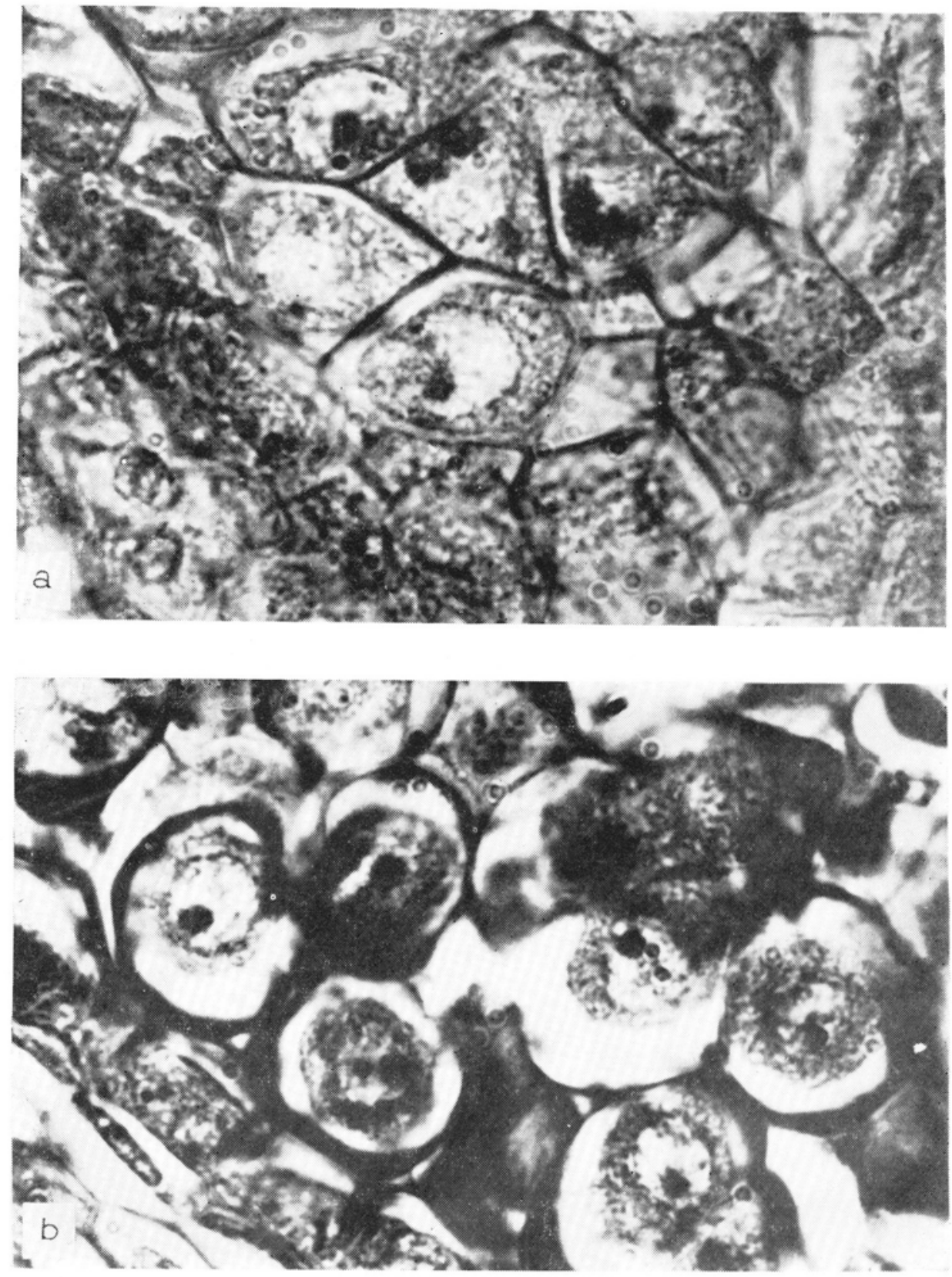

PMC's in Betula oycoviensis No. 39/A. a - synizesis; b - early prophase. 

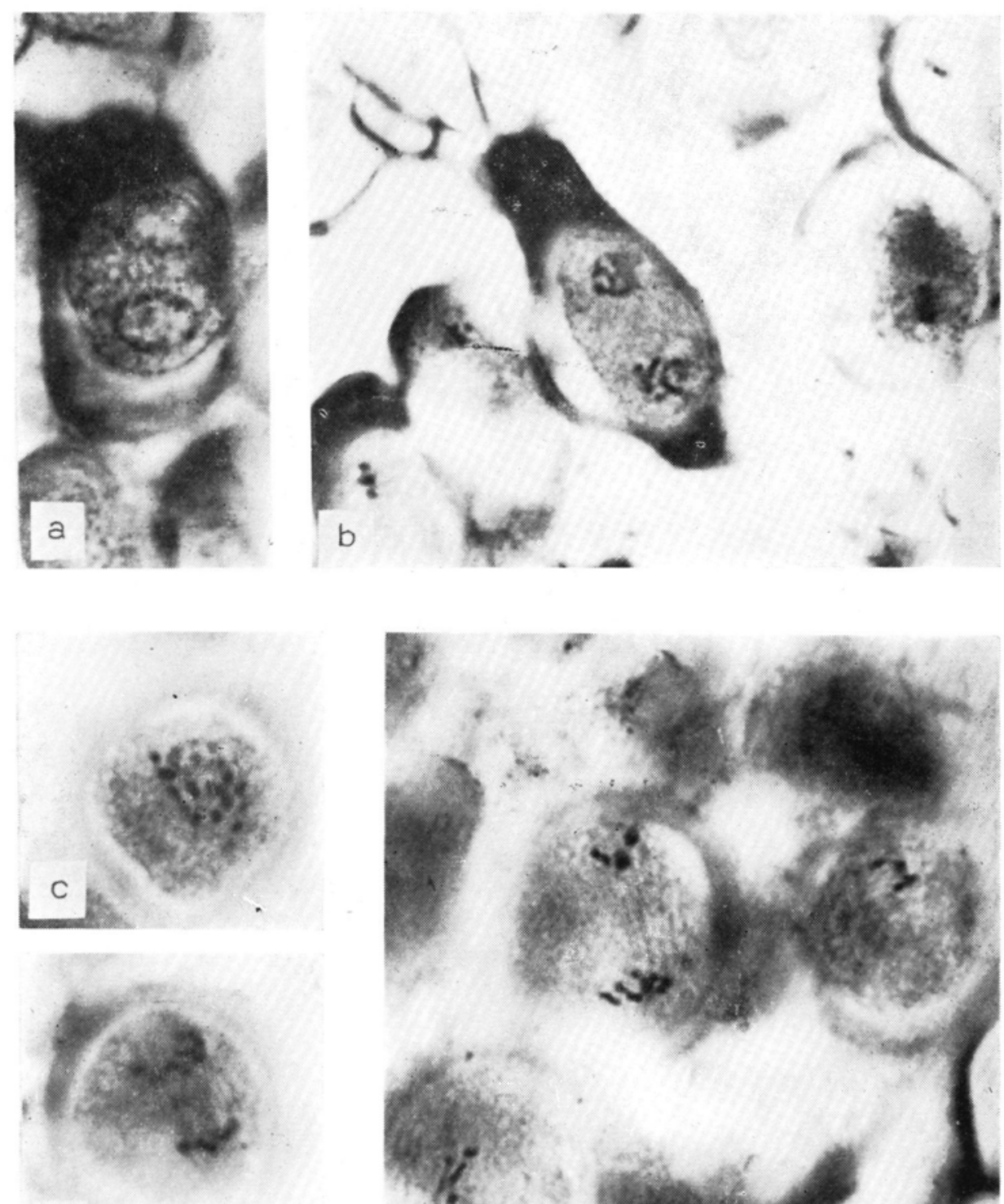

d

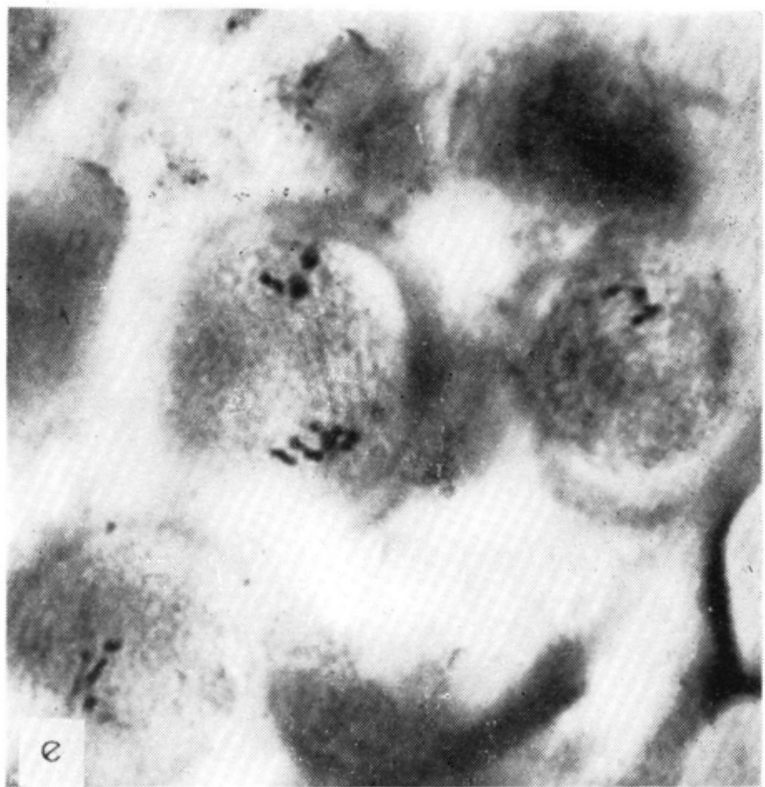

a - interkinesis with cell plate formation; b - metaphase II in B. oycoviensis from the Botanic Gardens; c - metaphase I in specimen No. 62/B of oycoviensis type; d, e - anaphase I in specimen No. 62/B. 

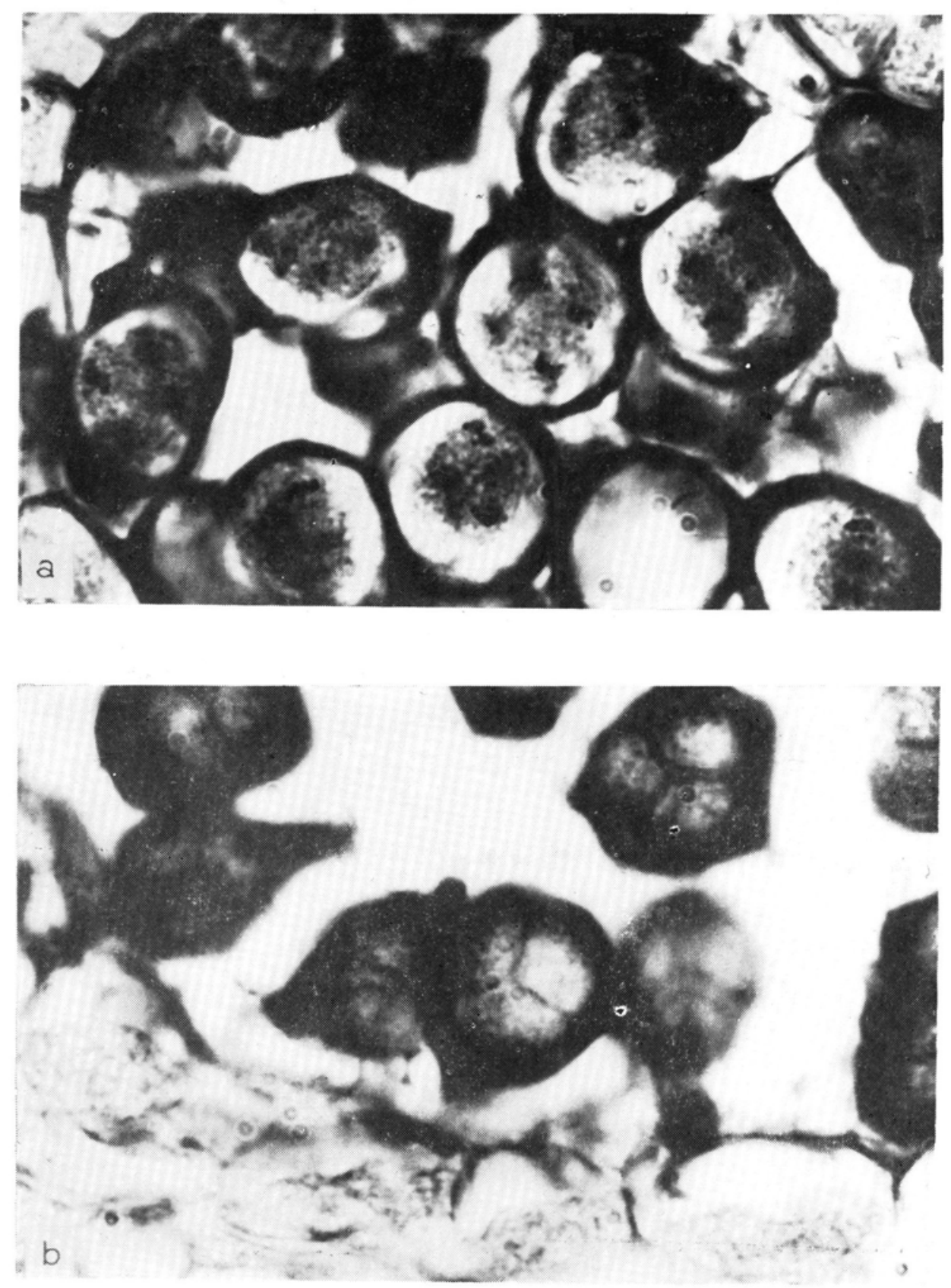

a - telophase II in B. oycoviensis No. 39/A; b - tetrads in No. 39/A. 
Table 3

Microsporogenesis of specimen No 62/B (oycoviensis type)

a.

Nu ber of

c s figurations

$\mathrm{N}$ un ber of cells

Metaphase I

Ana- and telophase I

Number of chromosomes or configurations*

b.

\begin{tabular}{c|c|c|c|c|c}
\hline $14+14$ & $14+14$ & $\begin{array}{l}14+14 \\
3 \text { elimin. }\end{array}$ & $14+5$ & $14+18$ & $14+$ min. 18 \\
\hline $14+18$ & $14+19$ & $\begin{array}{l}14+24 ? \\
3 \text { elimin. }\end{array}$ & $14+24 *$ & $16+20$ & $18+$ min. 22 \\
\hline \multirow{2}{*}{$16+25$} & $17+20$ & $\begin{array}{l}11+20 \\
3 \text { elimin. }\end{array}$ & $18+20^{*}$ & $3+11$ & $22+$ min. 19 \\
\hline
\end{tabular}

Metaphase II

c.

\begin{tabular}{l|c|c|c|c|c|c}
\hline $14+?$ & $14+?$ & $14+?$ & $14+7$ & $\begin{array}{c}14 ?+20 \\
1 \text { and } 2 \text { elim. }\end{array}$ & $14+$ numerous & $17+?$ \\
\hline \multirow{2}{*}{$18+?$} & $18+19$ & $21+24$ & $25+?$ & $\begin{array}{c}20+24 \\
3 \text { elimin. }\end{array}$ & $26+$ min. 21 & $28+?$ \\
\hline
\end{tabular}

Telophase II

Number of chromosomes

d.

\begin{tabular}{|c|c|c|c|}
\hline $\begin{array}{l}14 ?+7,14+18 \\
1 \text { eliminated }\end{array}$ & $\begin{array}{l}14+14,14 ?+14 \\
6 \text { eliminated }\end{array}$ & $\begin{array}{l}14+18,14+0 \\
4-5 \text { eliminated }\end{array}$ & $14+16,14+20$ \\
\hline
\end{tabular}

In telophase II, the chromosomes could be counted in only four cells, some chromosome groups, however, being very indistinct, hence the given values are but approximate, but they point to serious disturbances in the stage under observation. It was only in one of these cells that each of the four groups contained 14 chromosomes. One of the meiocytes lacked one of the four groups, only the middle of the cell being occupied by four chromosomes expelled from the spindle. Elimination of one or more chromosomes was detected in two other cells as well (Table 3d; Fig. 3c).

Owing to he above-described irregularities in the studied meiocytes, there was a tendency towards reduction of the number of chromosomes to $\mathrm{n}=14$, in both the ana- and telophase I, and also in meiotic division II. 
Disturbances in the progress of microsporogenesis in the specimen No. 62 resulted in the abnormal development of the tetrads (Fig. 3d). Among 100 of the counted tetrads, 54 contained one, two, less frequently three, and in one case even four additional cells. These cells varied in size from tiny microcytes, through medium-size cells, to, exceptionally, almost as
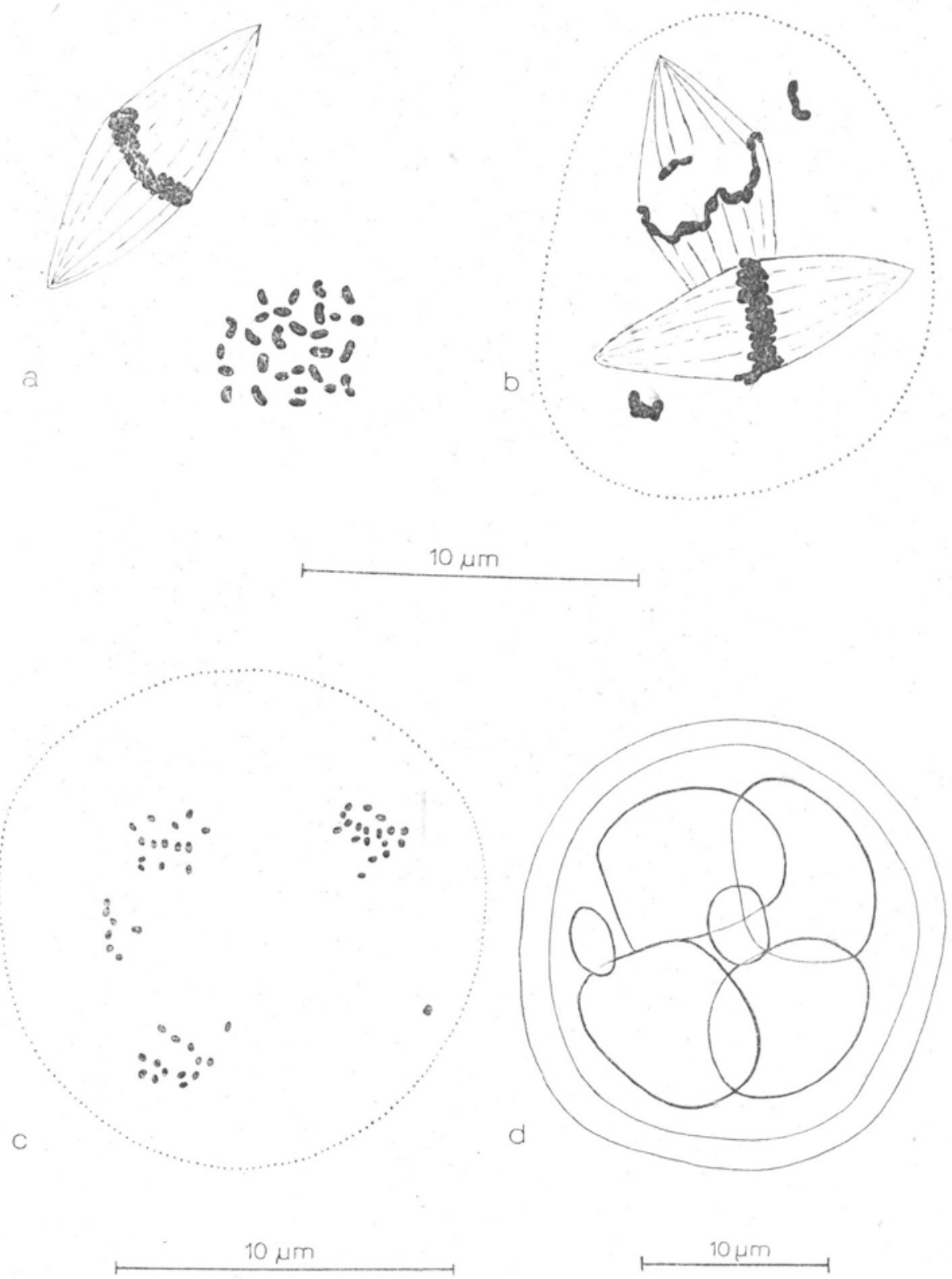

Fig. 3, Meiotic division II in birch No. 62/B of oycoviensis type. a, b - metaphase II; c - telophase II; d - tetrads 
big as normal tetrad sporocytes. A varying size of the four cells of the tetrad was another deviation from a norm observed even in apparently well developed tetrads. All such anomalies were bound to lead to abnormal development of pollen. The present author's earlier studies ( $\mathrm{S} \mathrm{z} \mathrm{w} \mathrm{a-}$ b ow i c z 1971) on the pollen of the progeny of B. oycoviensis have shown that in 1965 the pollen of specimen No. 62 from generation B contained $44 \%$ of grains completely devoid of cellular content, while $7 \%$ of them were only partly filled with it. The number of empty grains increased in the following year of investigation. Moreover, degeneration of pollen was manifested by the occurrence, on the one hand, of microcytes and, on the other, of grains with thickened sporoderm and greater number of pores; grains with 4, 5 up to 8 pores were often encountered. The viable grains demonstrated a wide range of variability in size but all were rather large, on the average larger than in other specimens of this generation.

\section{Verrucosa type}

The verrucosa type obtained as one of three segregates by the crossing of two specimens of $B$. oycoviensis, was represented in the studied material far more modestly than the oycoviensis type (Table 2). Telophase I, prophase and metaphase II were recorded only in the specimen No. 5 from generation B. The majority of the plates were found to contain 14 chromosomes each except for one cell which was very weakly stained and which arouse some doubt that the number of chromosomes in it was sligthly increased.

No tetrads were observed in this specimen. On the other hand, in the birch No. 43, also from generation B, and in verrucosa type No. 21 from generation $\mathrm{C}$ they were developed normally.

\section{Betula nova (nova type)}

The dwarf birch of the nova type which appeard unexpectedly among the progeny of B. oycoviensis, required a more detailed examination. To this end a number of self-pollinations and crossings of various specimens of this type from generation B were performed in the experimental plot (Table 1). It was also given more attention from the cytological point of view. In the ample fixed material 7 birches exhibited meiotic divisions, a few were found to contain only tetrads or already developed pollen grains, whereas the catkins of the remaining specimens turned out to be tco young to be studied for meiosis.

All the examined specimens from experimental breeding and the birch from the Kobylańska Valley (Table 2) revealed a normal course of divi- 
sions I and II. In diakinesis and metaphase I each meiocyte was found to contain 14 bivalents (Fig. $1 \mathrm{~d}, \mathrm{e}$ ), and in the plates of metaphase II and in groups of telophase II 14 chromosomes were ascertained. Deviations from a norm were very rare. In the birch No. 46 from generation B, for instance, a cell was encountered in which one plate contained 14 and the other over 20 chromosomes.

A great majority of the tetrads of birches of the nova type were developed quite rormally, anomalies occurring only sporadically. Three specimens were noted to contain one microcyte each. Likewise three times a tetrad was found in which one cell was slightly smaller than the remaining three.

Other akrormalities such as invagination of the external tetrad wall cr its excescive swelling, which could scmetimes be observed in the analysed material, were probably not related with microsporogenesis. Besides, in two cases an anther with somewhat deformed tetrads was encountered. This fhercmenon does not seem to have depended on meiotic divisions either.

\section{Tetrads and pollen grains}

A great many birches were found to contain the anthers with tetrads (Takle 2), probably owing to persistence of the tetrad stage, unlike meiotic divisions I and II, for a comparatively long time.

A characteristic appearance of the tetrads of the described types of linches was dve to the intensely stained protective callose "special wall", whose formaticn had already commenced in the stage of prophase and whose thickness increased in the course of meiosis (Plates II b and III b; F eslop-Harrison, 1966). In the birch tetrads it was developed similarly as in Helleborus foetidus L. (W a t e rke y n 1961, Figs 1-3), forming around the whole tetrade an uneven thicked wall and thinner walls around farticular microspores (Plate IV b).

As has already been mentioned, all the examined birches save the specimen of the oycoviensis type No. 62, had most of their tetrads normally developed, this pointing to the regular course of meiotic divisions and conditioning a normal formation of pollen grains.

Each microspore in the tetrad and immediately after leaving it was c. $8 \mu$ min diameter. In the oldest pollen grains observed in August and September, the diameter of $15 \mathrm{\mu m}$ prevailed (extreme values: 10.5 and $19.9 \mu \mathrm{m})$. The maximum values were attained by the pollen of the specimen of the oycoviensis type No. 141 from generation $\mathrm{H}_{7}$, which had been obtained by pollination of the birch of the nova type (No. 30/B) with the pollen collected from several specimens of $B$. verrucosa in the Wolski Wood. 
Only two microcytes were found in the analysed pollen grains, both of them in the nova type No. 3 from generation C, testifying to occasional disturbances in microsporogenesis.

The size of birch pollen found in the anthers in autumn was not rormal yet. In all likelihood it was only in spring that the pollen of all three types attained its normal diameter of c. $23 \mu \mathrm{m}$, and exceptionally c. $26 \mu \mathrm{m}$ in B. oycoviensis from generation $\mathrm{H}_{7}$ ( $\mathrm{S} \mathrm{zw}$ a bowicz 1971),

\section{DISCUSSION}

Microsporogenesis in both B. oycoviensis and 3 types of birches des. cending from it, i.e. oycoviensis, verrucosa, and nova types, did not exhikit any deviation from a norm save in one specimen of B. oycoviensis No. 62. It was cnly in isolated cases that the author observed anomalies in the course of meiotic divisions as well as some microcytes in the tetrads and among the already formed pollen grains.

Meiosis analysed, though not in all of its stages, in the specimen of the verrucosa type did not seem to vary from what had been ascertained by Anna Helms and C. A. J ø r g e n s en (1925) for the species B. verrucosa. Thus, the verrucosa type, belonging to the progeny of $B$. oycoviensis as one of its segregates and morphologically identical with the species B. verrucosa (J e n t y s-S z a f e r ow a 1967), showed slight or no abno:malities as regards meiotic divisions and pollen formation $(\mathrm{S} \mathrm{z} \mathrm{w} \mathrm{a} \mathrm{bo-}$ w i c z 1971).

The microsporogenesis of $B$. nova, investigated for the first time by the present author in a number of specimens, was regular. The poller of this birch was also well developed as the number of viable grains ranged between 78.5 and $98 \%$ for individual specimens ( $\mathrm{S} \mathrm{z} \mathrm{w} \mathrm{a} \mathrm{b} \mathrm{ow} \mathrm{i} \mathrm{c} \mathrm{z}$ 1971); moreover, judging by a number of successful self-pollinations and crosings a high degree of fertility was revealed not only by its poller but also ky its female gametes (Table 1; J en ty s-S za f e r ow a 1974).

$B$. nova, derived by experimental breeding and growing wild as one of the offspring of B. oyccviensis, has not till now been discovered outside the immediate vicinity of $B$. oycoviensis. It may well be that it did not attract anyone's attention, being regarded as a young B. oycoviensis or $B$. verrucosa, or that it does not exist any longer as an independent species in a natural state, the more so because it exhibits several lethal traits such as short life, excessive blossoming, and others.

From the genetic point of view, this birch, besides $B$. verrucosa, behaves like a parental species of $B$. oycoviensis. The reciprocal crossing of it with $B$. verrucosa yielded two very numerous, uniform generations of B. oycoviensis $\left(\mathrm{H}_{6}\right.$ and $\left.\mathrm{H}_{7}\right)$. 
Finally, the meiotic divisions observed in 7 specimens of the species and type oycoviensis, except for the birch No. 62, proceeded normally.

The birch No. 62 demonstrated disturbances in meiosis and abnormally developed pollen, thus the traits usually attributed to hybrids ( $\mathrm{S} \mathrm{a} \mathrm{x}$ 1935; Steb bins 1945). The earlier investigations on the karyology of birches have revealed a simultaneous presence in this specimen of some numbers of somatic chromosomes i.e. 28 , c. $35,36-38,40,42,45-48,52$ and c. 56 ( $\mathrm{S} \mathrm{zw}$ a bow i c z 1971). Therefore, it should be regarded as an akerrant form with a markedly disturbed cytological balance. Morphologically, this kirch exhibited a majority of the characters of B. oycoviensis, nevertheless, in the scatter diagram and in the diagram showing segregation of birches from generation B ( $\mathrm{J}$ e n t y s-S z a f e r o w a 1967, Figs 8, 12) it was found among $B$. oycoviensis birches which are most similar to B. verrucosa.

Extreme disturbances in microsporogenesis of this mixoploid birch resembled anomalies in the specimen of $B$. pendula Roth. $(=B$. verrucosa Ehrh.) from the Arnold Arberetum, most probably an natural hybrid, studied by Woodworth (1929), and even more the anomalies in one alloand one autotriploid specimen of $B$. verrucosa studied by Johns on (1944, Fig. 6), of which the first came from the crossing of B. verrucosa with B. pubescens. Similar abnormalities were also detected by $\mathrm{J}$ o h n ss o n $(1949$, Figs $7-10)$ in the meiosis of the hybrids $B$. pubescens $\times B$. papyrifera.

Unlike the specimen No. 62, the other investigated B. oycoviensis birches demonstrated a normal course of microsporogenesis. Likewise the pollen of these birches was well developed. However, these facts do not rule out the possibility that the species B. oycoviensis is a hybrid but may only point to a high degree of homology between the chromosome complexes of the parental species. Similarly, the hybrids $B$. verrucosa $\times B$. japonica, and B. verrucosa $\times$ B. papyrifera, described by $\mathrm{J}$ ohns son (1949, Figs 5, 6) did not deviate much from a norm in either the course of meiosis or pollen formation. S t e b b in s (1945), who fully accorded with S a x's opinion (1935) that hybrids are characterized by irregular meiotic divisions and pollen sterility, at the same time reported that only 11 genera of the hybrids examined in the period between 1935 and 1945 had been found to contain at least two univalents, and as many as 41 had exhibited a complete chromosome conjugation. As regards fertility of interspecific hybrids, it may range from absolute sterility to complete fertility, sterility affecting principally the pollen grains (D i lle man $\mathrm{n}$ 1954).

From the cytological point of view then, B. oycoviensis Bess. belong: to this kind of hybrids which does not manifest any irregularity in meiosis and possesses a well developed pollen. Numerous successful pollinations have also borne out its fertility as far as female gametes are concerned (Table 1; J e n ty s-S z a f e r ow a 1967, 1975). A hybrid character of this 
birch which for many years passed for a species, has been revealed only by segregation of its progeny. The crossing of two specimens of B. oycoviensis carried out in experimental breeding, at full fertility of the hybrid i.e. B. oycoviensis, produced such a result as can be observed in $F_{2}$ i.e. segregation according to Mendel's law (Dille mann 1954). The same process also took place in the Kobylańska Valley where a solitary specimen of B. oycoviensis became self-pollinated.

The present study was carried out in the Department of Pland Variability of the Institute of Botany of the Polish Academy of Sciences in Krakow. The author wishes to express her warm thanks to Professor Dr. hab. J a n in a J e n t y s-Szaf e row a for entrusting her with the studies on the cytology of B. oycoviensis and for her friendly care and supervision of the whole of the present author's work. Thanks are also due to Doc. Dr. hab. Romana Czapik for her help and valuable advice.

\section{REFERENCES}

Bess er W. S., 1809. Primiciae Florae Galiciae Austriacae utriusque, pars II, Sum. ant. Doll. Vienna.

Dille ma n n G., 1954. Bull. Sc. Bot. de France, 101 (1-2): 36-87.

H e $1 \mathrm{~m}$ s A., J ør g e n s en G. A., 1925. Bot. Tidsskr., 39 (2): 57-134.

H e s lo p-H a r r is on J., 1966. Ann. Bot., 30 (118): 221-230.

Jenty s-Sza ferowa J., 1921. Pol. Akad. Um., Flora Polska, 2: 3-17.

J e n t y s-S z a f er o w a J., 1928. Roczn. Pol. Tow. dendr., 2: 1-16.

Jent y s-Sza ferow a J., 1951. Bull. Acad. Pol. Sc. Lett. Ser. B: 1-40.

J en ty s-S z a f e r ow a J., 1953. Ochrona przyrody, 21: 33-57.

Jenty s-S z a f e row a J., 1967. Rocz. Sekc. dendr. 21: 5-56.

Jentys-Szaf erowa J., Bi $ł$ obrzeska M., Truchanowicz J., Więck o w s k a I., 1974. Fragm. Flor. et Geobot. 20 (2): 203-242.

J o h n s s on H., 1944. Bot. Not.: 85-96.

J o h n s s o n H., 1949. Hereditas, 35: 115-135.

K or c y k A., 1967a. Roczn. Sekc. dendr., 21: 77-103.

K or c z y k A., 1967b. Fragm. Flor. Geob. 13 (4): 493-497.

M a r in A., 1960. Stain Technology, 35 (6): 351-353.

S a x K., 1935. Bot. Rev., 1: 110-118.

St e b bins G. L., jr., 1945. Bot. Rev., 11: 463-486.

S z w a bowi c z A., 1971. Ac. Soc. Bot. Pol., 40 (1): 91-121.

S z w a bowi c z A., 1972. Ac. Soc. Bot. Pol., 41 (2): 235-252.

W a terkey n L., 1961. C. r. Hebd. Acad. Sc. (Paris), 252 (18): 4025-4027.

W i ęc k ow sk a I., 1967. Rocz. Sekc. dendr. 21: 57-76.

W inkler H., 1904. Betulaceae. Das Pflanzenreich. 19 (IV. 61): 56-101.

Wood worth R. H. 1929. Bot. Gaz. 87: 351-363.

Autor's Address:

Anna Szwabowicz

Institute of Botany

of the Polish Academy of Sciences,

Department of the Variability of Plants

Lubicz 46; 31-512 Kraków; Poland 
Streszczenie

Brzoza ojcowská, uważana przez długie lata za gatunek, po przeprowadzeniu krzyżowania Betula oycoviensis $\times$ B. oycoviensis, dała nieoczekiwanie potomstwo dzielące się na trzy typy brzóz: typ verrucosa, typ oycoviensis i typ nova, mniej więcej w stosunku 1:2:1. Dwa pierwsze typy były to drzewa, trzeci zaś okazał się małym krzewem. Fonadto wszystkie trzy typy różniły się szeregiem cech morfologicznych i biologicznych.

Przcbadano mikrosporogenezę u okazów B. oycoviensis, będących osobnikami rodzicielskimi w wymienionej krzyżówice, oraz u szeregu okazów potomnych, należących do trzech typów brzóz. Tylko u jednej brzozy typu oycoviensis, będącej okazem miksoploidalnym ( $\mathrm{s}$ w a b ow i c z 1972), miały miejsce zakłócenia w mikrosporogenezie, podobne do zaburzeń występujących u triploidów lub u niektórych mieszańców międzygatunkowych. Mejoza u innych przebadanych brzóz typu 'oycoviensis, verrucosa i nova miała przebieg prawidłowy i prowadzila do normalnie wykształconych tetrad oraz ziarn pyłku.

B. oycoviensis należy zatem do mieszańców, o regularnej mejozie, której charalitcr mieszańcowy ujawnia się przy krzyżowaniu. 